\title{
An Early Radiocarbon Date from a Prehistoric Site in Anderson County, Texas
}

Timothy K. Perttula

Heritage Research Center, Stephen F. Austin State University

Follow this and additional works at: https://scholarworks.sfasu.edu/ita

Part of the American Material Culture Commons, Archaeological Anthropology Commons, Environmental Studies Commons, Other American Studies Commons, Other Arts and Humanities Commons, Other History of Art, Architecture, and Archaeology Commons, and the United States History Commons

Tell us how this article helped you.

This Article is brought to you for free and open access by the Center for Regional Heritage Research at SFA ScholarWorks. It has been accepted for inclusion in Index of Texas Archaeology: Open Access Gray Literature from the Lone Star State by an authorized editor of SFA ScholarWorks. For more information, please contact cdsscholarworks@sfasu.edu. 


\section{An Early Radiocarbon Date from a Prehistoric Site in Anderson County, Texas \\ Creative Commons License \\ (c) (i) (8)}

This work is licensed under a Creative Commons Attribution-NonCommercial 4.0 International License 
Joumal of Northeast Texas Archaeology No. 16 (2002)

\section{AN EARLY RADIOCARBON DATE FROM A PREHISTORIC SITE IN ANDERSON COUNTY, TEXAS}

\section{Timothy K. Perttula}

Clyde Amick and Ed Furman, avocational archaeologists, have been investigating a prehistoric archaeological site in Anderson County, Texas, that became exposed when an asphalt company began to mine sand from an alluvial terrace along Town Creek (Amick n.d.). The archaeological site (4lAN115) is about $15 \mathrm{~km}$ west of Palestine, the county seat for Anderson County.

One of the mining cuts in the terrace exposed deep alluvial deposits and a conœentration of ash and charcoal from a feature, probably a hearth. The feature was exposed from $107-122 \mathrm{~cm}$ below the surface, and was found associated with several lithic flakes, a scraper, and a small flake knive. Amick and Furman excavated a $2 \times 2.5 \mathrm{ft}$. unit in the cutbank to better expose the feature, which turned out to be $51 \mathrm{~cm}$ in diameter. They collected the feature contents for analysis, and at my suggestion, provided the $30 \mathrm{~g}$ of charcoal from the feature for radiocarbon analysis. In addition to the scraper and flake tool, as well as local and non-local lithic flakes, the feature contained pieces of ferruginous sandstone fire-cracked rock.

The charcoal sample was submitted to Beta Analytic Inc. for radiocarbon dating, and the results indicate that the ash and charcoal feature, and the associated artifacts, were deposited at the site between $4400-4000$ years ago. This is about the beginning of the Late Archaic period in Northeast Texas. According to Beta Analytic Inc., the sample (Beta166266) has a measured radiocarbon age of $3840 \pm 50 \mathrm{~B} . \mathrm{P}$., with a $13 \mathrm{C} / 12 \mathrm{C}$ ratio of -27.1 o/oo. Conrecting for isotopic fractionation, the conventional radiocarbon age is $3810 \pm 50$ B.P. (Figure 1).

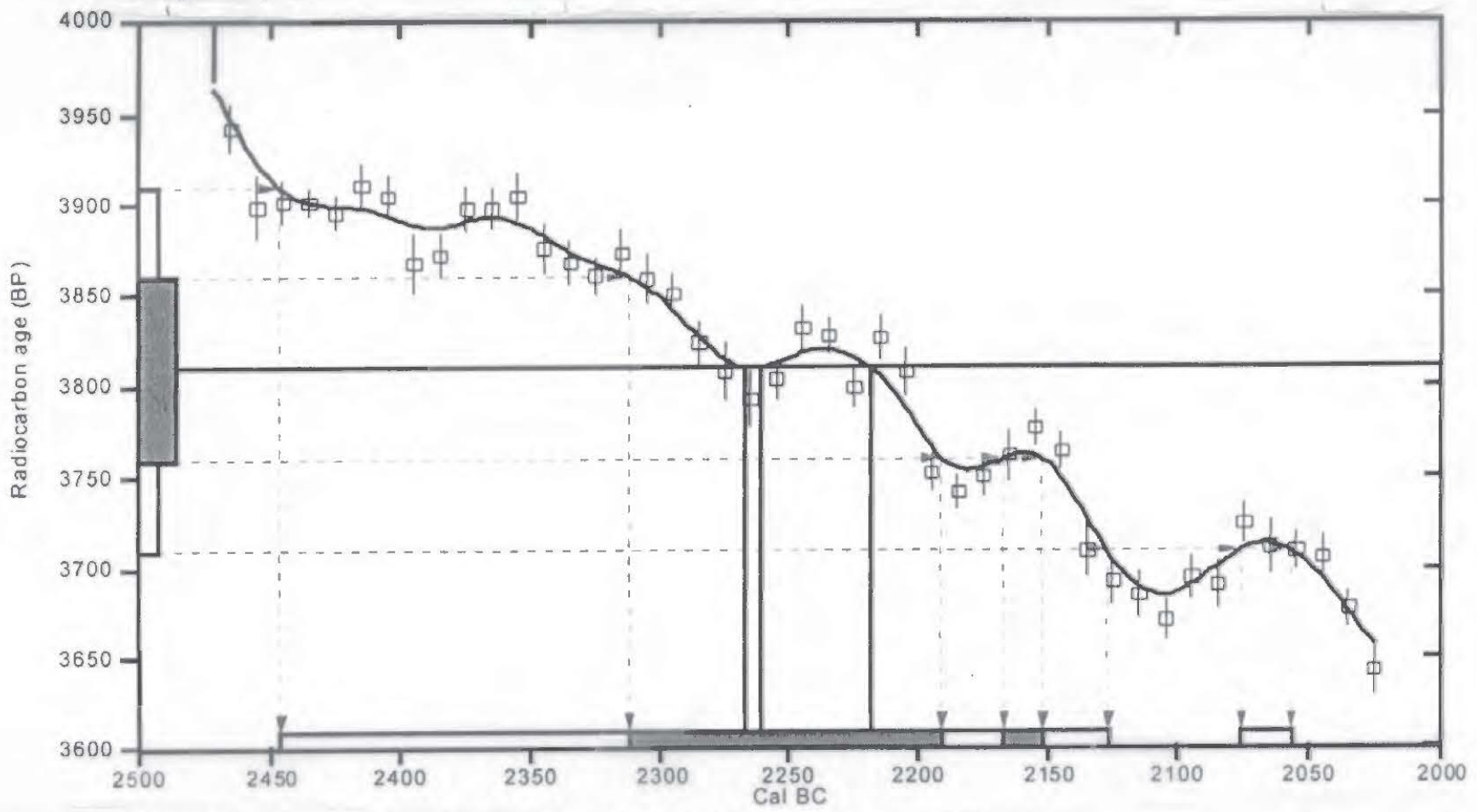

Figure 1. Calibration of Radiocarbon Date from 41AN1 15, Anderson County, Texas. 
Following Stuiver ct al. (1998) and Talma and Voge (1993), the one sigma and two sigma calibrated age ranges of the radiocarbon sample from $41 \mathrm{AN} 115$ are $4100-4260 \mathrm{~B}$.P. and 40104400 B.P., respectively. The two sigma calibrated results indicate that there is a 95\% probability that the ash and charcoal feature dates between 2060-2450 B.C., with calibrated intercepts at 2220 B.C., 2260 B.C., and 2270 B.C. (see Figure 1).

There are very few well-dated I ate Archaic archaeological components in Northeast Texas, based on a recent summary of radiocarbon and Oxidizable Carbon Ratio dates from prehistoric sites in the region (Penttula 1998). These include a buried shell lens at the Winston site (41 HE245) on the Trinity River that dates from 766-1084 B.C.; a buried scatter of burned rocks and lithic artifacts at the W. S. Long \#3 site (41HP118) in the South Sulphur River floodplain that dates from 924-1222 B.C.; and a small concentration of lithic tools and burned rocks at the Mockingbird site (41TT550) in the Big Cypress Creek basin that dates between 408-828 B.C. (Perttula 1998:310).

The preservation of deeply buried Late Archaic archaeological deposits and features with prcserved organic materials at 4IAN1 15 indicates that the site has considerable potential to shed new light on the settlement and subsistence strategies of Late Archaic peoples in Northcast Texas. Hopefully additional archaeological investigations can be conducted at 41 AN1 15 before it is destroyed by sand mining operations.

\section{REFFRENCES CITED}

Amick, C.

n.d. MS in preparation on the Fire pit Site (4IAN1 15).

Perttula, T. K.

1998 A Compendium of Radiocarbon and Oxidizable Carbon Ratio Dates from Archaeological Sites in East Texas, with a Discussion of the Age and Dating of Select Components and Phases. Radiocarbon 39(3):305-341.

Stuiver, M. et al.

1998 INTCAL98 Radiocarbon Age Calibration. Radiocarbon 40(3): 1041-1083.

Talma, A. S. and J. C. Vogel

1993 A Simplified Approach to Calibrating C14 Dates. Radiocarbon 35(2):317 322. 